\title{
The social media paradox: an intersection with freedom of expression and the criminal law
}

Article

Accepted Version

Coe, P. (2015) The social media paradox: an intersection with freedom of expression and the criminal law. Information and Communications Technology Law, 24 (1). pp. 16-40. ISSN 1360-0834 doi:

https://doi.org/10.1080/13600834.2015.1004242 Available at https://centaur.reading.ac.uk/86779/

It is advisable to refer to the publisher's version if you intend to cite from the work. See Guidance on citing.

To link to this article DOI: http://dx.doi.org/10.1080/13600834.2015.1004242

Publisher: Taylor \& Francis

All outputs in CentAUR are protected by Intellectual Property Rights law, including copyright law. Copyright and IPR is retained by the creators or other copyright holders. Terms and conditions for use of this material are defined in the End User Agreement.

www.reading.ac.uk/centaur 
Central Archive at the University of Reading

Reading's research outputs online 


\title{
The social media paradox: an intersection with freedom of expression and the criminal law
}

\author{
Peter $\operatorname{Coe}^{\mathrm{a}, \mathrm{b} *}$ \\ ${ }^{a}$ Aston University, Aston Law, Birmingham, UK, ${ }^{b}$ East Anglian Chambers, Norwich, UK
}

\begin{abstract}
This article begins by setting out the human rights provisions that apply to social media expression. It then provides insight into the part social media plays within our society by analysing the social media landscape and how it facilitates a 'purer' form of expression. The social media paradox is explored through the lens of current societal issues and concerns regarding the use of social media and how these have manifested into litigation. It concludes by analysing the tension that the application of an array of criminal legislation and jurisprudence has created with freedom of expression, and whether this can successfully mitigated by the Director of Public Prosecution's Interim Guidelines.
\end{abstract}

Keywords: social media; freedom of expression; criminal law

\section{Introduction}

The media landscape is undergoing profound change, on an unprecedented scale and at an exponential pace, at the forefront of which is social media. This communication revolution has been recognised within a variety of international arenas. For instance, in 2011, the United Nations (UN) Human Rights Committee (HRC) stated:

[I]nternet and mobile based electronic information dissemination systems, have substantially changed communication practices around the world. There is now a global network for exchanging ideas and opinions that does not necessarily rely on the traditional mass media intermediaries. ${ }^{1}$

On UN World Press Day in 2012, Abdulaziz Al-Nasser, the then President of the UN General Assembly, said: 'Governments that try to suppress or shut-down new media platforms should rather embrace new media for the beneficial transformation of their societies. ${ }^{2}$ Further, in early 2014, the House of Lords Select Committee on Communications Report on Media Plurality recognised the increasingly important role that new

\footnotetext{
*Email: p.coe@aston.ac.uk

${ }^{1}$ Human Rights Committee, General Comment 34: Freedoms of opinion and expression, CCPR/C/ GC/34 (GC 34) 12th September 2011, [15]; see also, O'Flaherty, Freedom of Expression: Article 19 of the ICCPR and Human Rights Committee's General Comment No 34, (2012) 12 Human Rights Law Review 627.

${ }^{2}$ UN Highlights Role of Press Freedom as Catalyst for Social and Political Change, UN News Centre $<$ http://www.un.org/apps/news/story.asp?NewsID=41911\&Cr=journalist\&Crl $>$ accessed 28 April 2014.
} 
media is playing within society. ${ }^{3}$ These views have been mirrored in the USA, where the influence of social media was summed up by the Criminal Court of the City of New York in New York $v$ Harris: 'The reality of today's world is that social media, whether it be Twitter, Facebook, Pinterest, Google+ or any other site, is the way people communicate'. ${ }^{4}$

Social media is both dynamic and organic. Platforms that have come to be synonymous with the terms 'social media' and 'social networking', such as Facebook and Twitter, are constantly evolving to meet, not only the needs and wants of their users, and the objectives of their owners, but also to compete against other, emerging platforms, and to continue to develop within the technological and economical infrastructures they inhabit. ${ }^{5}$

Due to its structural fluidity, social media has been defined in a number of ways. For instance, it has been said that it is 'a group of Internet-based applications that build on the ideological and technological foundations of Web 2.0, and that allow the creation and exchange of User Generated Content' ${ }^{6}$ It has also been described as

web-based services that allow individuals to (1) construct a public or semi-public profile within a bounded system, (2) articulate a list of other users with whom they share a connection, and (3) view and transverse their list of connections and those made by others within the system. ${ }^{7}$

These definitions recognise social media as a tool that has changed the way in which we communicate, giving rise to a culture of sharing and voluntariness. ${ }^{8}$ According to Professor Van Dijck, social media has created a new: 'online layer through which people organise their lives ... this layer of platforms influences human interaction on an individual and community level, as well as on a larger societal level, while the worlds of online and offline are increasingly interpenetrating,?

This article will begin by setting out the human rights provisions that apply to social media expression. It will then consider the social media landscape and how it facilitates a 'purer' form of expression. Current issues and concerns regarding the use of social media are explored to set the scene and provide context for the final section, which looks at how some of these issues have translated into criminal litigation and how the law has coped with social media expression to date.

\section{Human rights: the legal landscape}

The principles and accepted norms relating to the operation of social media expression, pursuant to human rights treaties and jurisprudence, predominantly emanate from an era that

\footnotetext{
${ }^{3}$ House of Lords Select Committee on Communications 1st Report of Session 2013-14, Media Plurality, 4th February 2014, [46]-[52].

${ }^{4}$ New York v Harris, 2012 N.Y. Misc. LEXIS $1871 * 3$, note 3 (Crim. Ct. City of N.Y., N.Y. County, 2012).

${ }^{5}$ J. Van Dijck, The Culture of Connectivity A Critical History of Social Media (Oxford University Press, 2013), 7.

${ }^{6} \mathrm{AM}$. Kaplan and M Haenlein, Users of the world, unite! The challenges and opportunities of Social Media, Business Horizons (2010) 53, 59-68, 61.

${ }^{7}$ DM. Boyd and NB. Ellison (2007), Social Network Sites: Definition, History and Scholarship, Journal of Computer-Mediated Communication, 13: 210-30, 211.

${ }^{8}$ DR. Stewart (ed), Social Media and the Law (Routledge, 2013), viii; see also, C. Shirky, Here Comes Everybody (Allen Lane, 2008), 17.

${ }^{9}$ Van Dijck (n 5), 4.
} 
could not have envisaged the social media revolution. Despite this, expression, via social media platforms, is subject to these various provisions. This section sets out the relevant framework under both the International Covenant on Civil and Political Rights (ICCPR) and the European Convention on Human Rights (ECHR).

\subsection{International Covenant on Civil and Political Rights}

Article 19(2) of the ICCPR, to which the UK is a signatory, states:

Everyone shall have the right to freedom of expression; this right shall include freedom to seek, receive and impart information and ideas of all kinds, regardless of frontiers, either orally, in writing or in print, in the form of art, or through any other media of his choice.

According to the UN Human Rights Council Special Rapporteur's Report on the promotion and protection of the right to freedom of opinion and expression, this provision applies to the internet, ${ }^{10}$ as it has become a means by which individuals can facilitate their right to freedom of opinion and expression. It provides access to information that was previously unobtainable, and therefore contributes to the discovery of truth and the progress of society. ${ }^{11}$ In addition to the internet generally, the report states that Article 19(2) was drafted with foresight to cover advances in technology through which expression can be made. ${ }^{12}$ The HRC has suggested that methods of expression include: 'all forms of electronic and internet-based modes of expression'. ${ }^{13}$ Thus, clearly, in the eyes of the HRC, this renders the provision relevant and applicable to new and emerging communication technology, such as social media platforms.

The HRC has also recognised that certain forms of expression can be subject to restriction. ${ }^{14}$ To ensure the legitimacy of any such restriction on freedom of expression, the regulatory/legislative framework and/or jurisprudential reasoning in question must fall within the parameters of Article 19(3). ${ }^{15}$ These frameworks must provide for the differences between the print, broadcast and internet media sectors, while also taking into account their convergence. ${ }^{16}$ Any restrictions that are imposed on the operation of internet-based search providers or communication platforms, including social media, must fall within the parameters of Article 19(3), which provides:

The exercise of the rights provided for in paragraph 2 of this Article carries with it special duties and responsibilities. It may therefore be subject to certain restrictions, but these shall only be such as are provided by law and are necessary: (a) For respect of the rights or reputations of

\footnotetext{
${ }^{10} \mathrm{~F}$. La Rue, Report of the Human Rights Council's Special Rapporteur on the promotion and protection of the right to freedom of opinion and expression, A/HRC/17/27, 16th May 2011, [21]; see also, UN General Assembly Human Rights Council, The promotion, protection and enjoyment of human rights on the Internet, Resolution 20/8, A/HRC/RES/20/8, 29th June 2012, [1].

${ }^{11}$ Ibid. [19].

${ }^{12}$ La Rue (n 10), [21].

${ }^{13}$ UN Human Rights Committee, General Comment 34: Freedoms of Opinion and Expression, CCPR/ C/GC/34 (GC 34) 12 September 2011, [12].

${ }^{14}$ Ibid, [11]; see also, F. La Rue, Report of the Human Rights Council's Special Rapporteur (n 10), [25].

${ }^{15}$ La Rue (n 10), [23]-[24]; see also, UN Human Rights Council, Promotion and protection of all human rights, civil, political, economic, social and cultural rights, including the right to development, Fourteenth Session, A/HRC/14/23, 20th April 2010, [72]-[87].

${ }^{16}$ UN Human Rights Committee (n 13), [34].
} 
others; (b) For the protection of national security or of public order (ordre public), or of public health or morals.

Although, in Ross $v$ Canada, ${ }^{17}$ Article 19(2) was held to encapsulate expression that may be deemed deeply offensive, ${ }^{18}$ the HRC has stated that such expression, in different circumstances, could give rise to legitimate restriction pursuant to $19(3) .{ }^{19}$ Other forms of expression that can be subject to permissible restriction under the provision include, inter alia: hate speech; ${ }^{20}$ defamation; advocacy of national, racial or religious hatred that constitutes incitement to discrimination, hostility or violence. ${ }^{21}$

\subsection{ECHR and the European Court of Human Rights}

Article 10(1) ECHR provides:

Everyone has the right to freedom of expression. This right shall include freedom to hold opinions and to receive and impart information and ideas without interference by public authority and regardless of frontiers.

Article 10(1) is qualified by Article 10(2), which states:

The exercise of these freedoms, since it carries with it duties and responsibilities, may be subject to such formalities, conditions, restrictions or penalties as are prescribed by law and are necessary in a democratic society, in the interests of national security, territorial integrity or public safety, for the prevention of disorder or crime, for the protection of health or morals, for the protection of the reputation or rights of others, for preventing the disclosure of information received in confidence, or for maintaining the authority and impartiality of the judiciary.

The jurisprudence of the European Court of Human Rights (ECtHR), as stated in Handyside $v$ United Kingdom, ${ }^{22}$ is very similar to that of the $\mathrm{HRC},{ }^{23}$ as it determines that freedom of expression includes the right to say things or express opinions 'that offend, shock or disturb the state or any sector of the population'. ${ }^{24}$

In order to determine whether particular expression has been subject to legitimate restriction within the confines of 10(2), the ECtHR, and domestic courts, have attributed a hierarchical value ${ }^{25}$ to different types of expression.

\footnotetext{
${ }^{17} 18$ October 2000, Communication No. 736/1997.

${ }^{18}$ See also UN Human Rights Committee (n 13), [34].

${ }^{19}$ Ibid. However, these 'different circumstances' have not been specified.

${ }^{20}$ See Faurisson v France, UN Human Rights Committee, communication 550/1993, views of 8th November 1996.

${ }^{21}$ La Rue (n 10), [25].

${ }^{22}$ A 24 (1976); 1 EHRR 737.

${ }^{23} 18$ October 2000, Communication No. 736/1997; UN Human Rights Committee (n 13), [34].

${ }^{24}$ Handyside (n 22), [49]; see also, Éditions Plon v France App. No 58184/00 ECHR 2004-IV, [42][43].

${ }^{25}$ The high/low level speech terminology was developed in the USA through scholarship on the First Amendment. See J. Rowbottom, To rant, vent and converse: protecting low level digital speech, C.L. J. 2012, 71(2), 355-83, 368 citing C. Sunstein, Democracy and the Problem of Free Speech (New York: 1993), 122-23. See generally: L. Scaife, The DPP and social media: a new approach coming out of the Woods? Comms. L. (2013), 18(1), 5-10, 8.
} 
According to ECtHR jurisprudence, political expression affords the strongest protection. ${ }^{26}$ This view has been mirrored by the House of Lords. ${ }^{27}$ For instance, in Campbell $v M G N,{ }^{28}$ Baroness Hale stated:

The free exchange of information and ideas on matters relevant to the organisation of the economic, social and political life of the country is crucial to any democracy. Without this it can scarcely be called a democracy at all. ${ }^{29}$

Within the value hierarchy political expression is followed, first, by artistic expression, ${ }^{30}$ and then by commercial expression, ${ }^{31}$ both of which attract intermediate protection. ${ }^{32}$ Under this comes celebrity gossip, ${ }^{33}$ and then pornography. ${ }^{34}$ Finally, at the very bottom of the hierarchy, and attracting little, if any protection, are gratuitous personal attacks ${ }^{35}$ and hate speech. ${ }^{36}$

In Fuentes Bobo $v$ Spain, ${ }^{37}$ the ECtHR determined that, in deciding whether particular expression is of high or low value, it would have regard to whether the author had the opportunity to prepare what was expressed and whether there has been a 'possibility of reformulating, perfecting or retracting' ${ }^{38}$ the content of the expression before it is made available to the public. ${ }^{39}$ This is particularly relevant in the context of social media as platforms for user speech, as discussed in the following section.

Pursuant to section 6 of the Human Rights Act 1998 (HRA), it is unlawful for prosecutors and judges to act incompatibly with ECHR rights. Further, section 3 of the HRA requires judges to interpret legislation compatibly with ECHR rights, if it is possible to do so. In addition, the jurisprudence of the ECtHR and the HRC is clear: there is a right to expression that is offensive, shocking or disturbing. ${ }^{40}$ Thus, as dealt with in section 5 ,

\footnotetext{
${ }^{26}$ TV Vest As \& Rogaland Pensjonistparti v Norway [2008] ECHR 21132/05, [59]; Lingens v Austria (1986) 8 E.H.R.R. 407, [42]; Wingrove v United Kingdom (1997) 24 E.H.R.R. 1, [58]; United Communist Party of Turkey v Turkey (1998) 26 E.H.R.R. 121, [45]; Nilsen v Norway (2000) 30 E.H.R.R. 878, [46]; Vgt Verein gegen Tierfabriken (2002) 34 E.H.R.R. 4, [66]; Murphy v Ireland (2004) 38 E.H. R.R. 13, [67].

${ }^{27}$ See $R$ (ProLife Alliance) v BBC [2003] UKHL 23, [6] per Lord Nicholls; $R$ v Shayler [2002] UKHL 11, [21] per Lord Bingham.

${ }^{28}$ [2004] UKHL 22.

${ }^{29}$ Ibid. [148].

${ }^{30}$ Muller v Switzerland (1991) 13 E.H.R.R. 212; Otto Preminger v Austria (1995) 19 E.H.R.R. 34; IA v Turkey (2007) E.H.R.R. 30.

${ }^{31}$ Markt Intern v Germany (1989) 12 E.H.R.R. 161, [33].

${ }^{32}$ Rowbottom (n 25), 368.

${ }^{33}$ Campbell (n 28), [149].

${ }^{34}$ Belfast City Council v Miss Behavin' Ltd [2007] UKHL 19, [38].

${ }^{35}$ Gorelishvili v Georgia (2009) 48 E.H.R.R. 36, [40].

${ }^{36}$ Lehideux and Isornia $v$ France (1998) 5 B.H.R.C. 540, [53]; Norwood $v$ United Kingdom (2004) 40 E.H.R.R. SE 111.

${ }^{37}(2001) 31$ E.H.R.R. 50.

${ }^{38}$ Ibid. [46].

${ }^{39}$ See generally: L. Scaife, The DPP and social media: a new approach coming out of the Woods? Comms. L. (2013), 18(1), 5-10.

${ }^{40}$ Handyside (n 22); EHRR 737 [49]; Ross v Canada 18 October 2000, Communication No. 736/ 1997; UN Human Rights Committee, General Comment 34: Freedoms of Opinion and Expression, CCPR/C/GC/34 (GC 34) 12th September 2011, [11].
} 
the potential for social media activity to conflict with freedom of expression is most obvious when expression is criminalised. ${ }^{41}$

\section{The (social) media landscape: platforms for a 'purer' form of expression?}

The origins of the traditional media, and in particular the press industry, may well be founded on freedom of expression philosophy, ${ }^{42}$ and the notion that, as 'the fourth estate', its primary function is to act as a 'public watchdog, ${ }^{43}$ in that it operates as the general public's 'eyes and ears' by investigating and reporting abuses of power. ${ }^{44}$ However, it is submitted that media ownership, and the power derived from it, means that there is a constant conflict between these underpinnings and commercial reality. Consequently, until relatively recently, the public were, to a greater extent, limited as to what they were exposed to reading or seeing, by what large proportions of the traditional media chose to publish or broadcast. Such decisions may have come down to editorial control, based on, for instance, owner or political bias, commercial revenue or both.

Social media platforms have changed this media landscape forever, as they have altered our perceptions of the limits of communication and reception of information. It is no longer the case that communication is constrained by boundaries, such as location, time, space or culture. ${ }^{45}$ The gradual erosion of these boundaries is borne out by recent Office for National Statistics data, which states that, in 2013, $83 \%$ of Great British households had internet access. Thirty-six million (73\%) adults in Great Britain used the internet every day, equating to 20 million more than that in 2006; with 53\% using a mobile phone to access it remotely, more than double the 2010 figure of $24 \% .{ }^{46}$ These figures are reflected by recent statistics from the USA and the EU. As of May 2013, 80\% of American adults had either a broadband connection at home, or a smartphone or both. ${ }^{47}$ In 2012, the percentage

\footnotetext{
${ }^{41}$ D. McGoldrick, The Limits of Freedom of Expression on Facebook and Social Networking Sites: A UK Perspective, HRLR 13 (2013), 125-51, 131 citing A. Bailin, Criminalising Free Speech? (2011) Criminal Law Review, 9, 705-11.

${ }^{42}$ For detailed discussion on freedom of expression philosophy see, for instance: E. Barendt, Freedom of Speech (2nd ed. Oxford University Press, 2005); F. Schauer, Free Speech: A Philosophical Enquiry (Cambridge University Press, 1982); L. Alexander, Is there a Right to Freedom of Expression (Cambridge University Press, 2005); T. Campbell and W. Sadurski, Freedom of Communication (Dartmouth, 1994); JM. Bakin, Digital Speech and Democratic Culture: A Theory of Freedom of Expression for the Information Society (2004) 79 New York U LR 1.

${ }^{43}$ Observer and Guardian v UK (1992) 14 EHRR 153, [59].

${ }^{44} A-G$ v Guardian Newspapers Ltd (No. 2) [1990] 1 AC 109, 183 per Sir John Donaldson MR; see also Barendt (n 42), 418.

${ }^{45}$ See generally: F. Webster, Theories of the Information Society (4th edn, Routledge, 2014), 20; I. Barron and R. Curnow, The Future with Microelectronics: Forecasting the Effects of Information Technology (Pinter, 1979); G. Mulgan, Communication and Control: Networks and the New Economies of Communication (Polity, 1991).

${ }^{46}$ Indeed, if you add 'portable computers' to this, the percentage of people accessing the internet 'on the go' in 2013 rises to 61\%: Office for National Statistics, Internet Access - Households and Individuals, 2013, 8 August $2013<\mathrm{http} / / /$ www.ons.gov.uk/ons/dcp171778_322713.pdf> accessed 27 March 2014.

${ }^{47}$ The $80 \%$ breaks down as follows: $46 \%$ have both home broadband connection and a smartphone; $24 \%$ have home broadband connection but no smartphone; $10 \%$ have a smartphone, but not home broadband connection: K. Zickurh and A. Smith, Home Broadband 2013, PewResearch Internet Project, 26 August $2013<$ http://www.pewinternet.org/2013/08/26/home-broadband-2013/>; A. Smith, Smartphone Ownership 2013, PewResearch Internet Project, 5 June $2013<$ http://www. pewinternet.org/2013/06/05/smartphone-ownership-2013/> both accessed 27 March 2014.
} 
of individuals in the EU who used the internet was 73\%, 30\% of which gained access via mobile devices away from home or work. ${ }^{48}$ Worldwide, the estimated number of internet users exceeds two billion. ${ }^{49}$

Our access to multiple social media outlets and platforms 24 hours a day that, due to mobile phones, tablets and laptops, can be accessed instantaneously, regardless of location or time, is symptomatic of how new media has evolved to take full advantage of this transcendence of traditional boundaries. Thus, users, forming what Benkler refers to as the 'networked public sphere, ${ }^{50}$ can transmit and receive information to one and other, via platforms, such as YouTube, Facebook, Twitter, WhatsApp and Snapchat, without the need to consider, what have become, the arbitrary boundaries mentioned above. When in place, these boundaries acted as a natural filtration system for news and information. Their dilution has enabled real-time relationships to exist without any physical interaction. ${ }^{51}$ Consequently, Professor McLuhan's proclamation, that the 'medium is the message', ${ }^{52}$ seems both prophetic and entirely apt for the social media era as, according to McLuhan, the media is an extension of ourselves, and new mediums introduced into our lives give rise to personal and social consequences, as a result of that new 'extension'. 53 Accordingly: 'the message of any medium or technology is the change of scale or pace or pattern that it introduces into human affairs'. ${ }^{54}$

The way in which the media envelopes our existence is amplified by social media. Platforms such as Facebook and Twitter have become an embodiment of McLuhan's 'extension of man', and a facilitator of unfiltered expression, by being platforms for user speech, as opposed to that of a media organisation's ownership, employees or political stance. Traditional media organisations simply no longer monopolise the methods we use to find and facilitate news-gathering, communication or reception, or indeed how we express opinions and ideas. For instance, the death of Osama Bin Laden was leaked on Twitter, before being published by any newspaper. ${ }^{55}$ Edward Snowden disclosed information regarding American surveillance programmes to blogger Glenn Greenwald, as he did not trust the New York Times to publish the material. ${ }^{56}$ Syria's President, Bashar al-Assad, and his opposing rebels distribute competing propaganda via Instagram. ${ }^{57}$ Chelsea Manning, the US soldier convicted in 2013 for, inter alia, offences pursuant to the

\footnotetext{
$\overline{{ }^{48} \mathrm{H} \text {. Seybert, Internet use in households and by individuals in 2012, Eurostat, } 2012<\mathrm{http}: / / \mathrm{epp}}$. eurostat.ec.europa.eu/cache/ITY_OFFPUB/KS-SF-12-050/EN/KS-SF-12-050-EN.PDF> accessed 27 March 2014.

${ }^{49}$ La Rue, Report of the Human Rights Council's Special Rapporteur (n 10), [21]; see also, UN General Assembly Human Rights Council, The promotion, protection and enjoyment of human rights on the Internet, Resolution 20/8, A/HRC/RES/20/8, 29 June 2012, [2].

${ }^{50}$ Y. Benkler, The Wealth of Networks (Yale University Press, 2006), 212.

${ }^{51}$ B. Wellman, Physical Space and Cyberspace: The Rise of Personalised Networking, International Journal of Urban and Regional Research 25(2), 227-51.

${ }^{52}$ M. McLuhan, Understanding Media The Extensions of Man (MIT Press, 1964), 7.

${ }^{53}$ Ibid.

${ }^{54}$ McLuhan (n 52), 8.

${ }^{55} \mathrm{~B}$. Shelter, How the Bin Laden Announcement Leaked Out, New York Times, 1 May $2011<\mathrm{http}: / /$ mediadecoder.blogs.nytimes.com/2011/05/01/how-the-osama-announcement-leaked-out/?_php=true\&_type $=$ blogs\&_r $=0>$ accessed 12 September 2014.

${ }^{56}$ M. Ammori, The "new" New York Times: Free speech lawyering in the age of Google and Twitter, Harvard Law Review, 2014, vol. 127: 2259-95, 2265.

${ }^{57}$ N. Gaouette, Assad on Instagram Vies with Rebel Videos to Seek Support, Bloomberg, 19 September $2013<$ http://www.bloomberg.com/news/2013-09-19/assad-on-instagram-vies-with-rebel-videos-toseek-support.html> accessed 12 September 2014.
} 
Espionage Act, leaked classified documents to WikiLeaks, as opposed to a 'traditional' media outlet. $^{58}$

Thus, never before has a form of media changed the 'scale, pace or pattern' of human affairs to such an extent, within such a short period of time. ${ }^{59}$ These platforms are used as a way of, not only receiving news, ${ }^{60}$ but also of instantaneously, and often spontaneously, without filter, expressing opinions and venting and sharing emotions, thoughts and feelings, ${ }^{61}$ circumventing the mass media, and giving rise to a convergence of audience and producer. ${ }^{62}$ This is illustrated by using statistics to compare the use of new, and in particular social, media with traditional media. For example, the New York Times 2013 print and digital circulation was approximately two million, ${ }^{63}$ enabling it to proclaim that it was the '\#1 individual newspaper site' on the internet, with nearly 31 million unique visitors per month. ${ }^{64}$ In contrast, YouTube, which is owned by Google, has one billion unique visitors per month ${ }^{65}$ which, according to Marvin Ammori, equates to: 'thirty times more than the New York Times, or as many unique visitors in a day as the [New York] Times has every month' ${ }^{66}$ Incidentally, Google's search engine reached a billion monthly users in $2011 .^{67}$ According to WordPress' statistics, it hosts blogs written in over 120 languages, equating to over 409 million users viewing more than 15.8 billion pages each month. Consequently, users produce approximately 43.7 million new posts and 58.8 million new comments on a monthly basis. These users can choose to create and maintain anonymous blogs. Moreover, companies such as CNN, UPS and NBC Sports use the facility to manage their sites. ${ }^{68}$ Twitter states that it normally 'takes in' approximately 500 million Tweets per day, equating to an average of 5700 Tweets per second. ${ }^{69}$ It has more visitors per week than the New York Times does in a month. ${ }^{70}$ Similarly, Tumblr hosts over 170 million microblogs ${ }^{71}$ and, with 300 million visits per month, enjoys 10 times more than the New York Times. ${ }^{72}$ According

\footnotetext{
${ }^{58}$ Benkler (n 50), 348 .

${ }^{59}$ Consequently, Time magazine named 'You' the person of the year in 2006: 'for seizing the reins of the global media, for founding and framing the new digital democracy, for working for nothing and beating the pros at their own game.' See L. Grossman, You-Yes, You-Are TIME'S Person of the Year, Time, 25 December $2006<$ http://content.time.com/time/magazine/article/0,9171,1570810,00.html> accessed 18 September 2014.

${ }^{60}$ According to Ofcom's report, The Communications Market 2013 (at para. 1.9.7), 23\% of people use social media platforms, such as Facebook and Twitter, for news: <http://stakeholders.ofcom.org.uk/ binaries/research/cmr/cmr13/UK_1.pdf> accessed 19 March 2014.

${ }^{61}$ Indeed, in April 2014 Facebook emailed its users to inform them that the messages function is moving out of the Facebook application due to their Messenger application enabling users to reply $20 \%$ faster than using Facebook.

${ }^{62}$ See generally: Rowbottom (n 25), 365 .

${ }^{63}$ C. Haughney, Newspapers Post Gains in Digital Circulation, New York Times, 30 April 2014 $<$ http://www.nytimes.com/2013/05/01/business/media/digital-subscribers-buoy-newspapercirculation.html > accessed 12 September 2014

${ }^{64}$ New York Times Media Kit <http://perma.cc/B5KA-VMGC> accessed 12 September 2014.

${ }^{65}$ Statistics YouTube <http://perma.cc/S8W5-ZRM4> accessed 12 September 2014.

${ }^{66}$ Ammori (n 56), 2266.

${ }^{67} \mathrm{Ibid}$

${ }^{68}<$ http://en.wordpress.com/stats/> accessed 22 September 2014.

${ }^{69}<$ https://blog.twitter.com/2013/new-tweets-per-second-record-and-how $>$ accessed 14 March 2014.

${ }^{70}$ Ammori (n 56).

${ }^{71}$ Ibid. 2272.

${ }^{72}$ J. Yarow, The Truth About Tumblr: Its Numbers Are Significantly Worse than You Think, Business Insider, 21 May $2013<\mathrm{http}$ //www.businessinsider.com/tumblrs-active-users-lighter-than-expected2013-5> accessed 12 September 2014.
} 
to Facebook, as of 31 December 2013, it had 1.23 billion monthly active users, 945 million of which use their mobile applications. ${ }^{73}$ Late 2013 saw Instagram's global usage expand by $15 \%$, in just two months, to 150 million people. ${ }^{74}$ LinkedIn's current membership is 277 million. ${ }^{75}$ These established platforms are only the 'tip of the new media iceberg'. Pinterest continues to grow rapidly, ${ }^{76}$ as do emerging platforms, such as Snapchat and WhatsApp. ${ }^{77}$ Consequently, for many people, social media platforms have not just replaced the written word; but they also have become a substitute for the spoken word.

\section{Issues and concerns regarding the use of social media: setting the 'social media paradox' scene}

It is clear that social media, as an extension of man, can liberate and empower individuals, regardless of social status. ${ }^{78}$ It has borne millions of 'publishers' who are able to circumvent the traditional mass media. On the one hand, it is arguable that this can only be good for freedom of expression and, incidentally, freedom of thought. These 'publishers' are not subject to the filter system discussed above and, for instance, political bias, censorship, the influence of media ownership or editorial control. In many ways, social media facilitates freedom of expression in its purest form.

On the other hand, however, this power can intoxicate individuals, who are perhaps not prepared for the responsibility that comes with its use, and leads them to communicate as though they operate within a "Wild West", law free zone in Cyberspace'. ${ }^{79}$ According to McGoldrick, this has led to 'catastrophic consequences' ${ }^{80}$ For example, individuals in the UK, and elsewhere, have been convicted of criminal offences, ${ }^{81}$ investigated by the Federal Bureau of Investigation, ${ }^{82}$ sued for

\footnotetext{
${ }^{73}<$ https://newsroom.fb.com/key-Facts $>$ accessed 14 March 2014.

${ }^{74}<\mathrm{http}$ ://instagram.com/press/\#>; UK Social Media Statistics for $2014<\mathrm{http}: / /$ socialmediatoday.com/ kate-rose-mcgrory/2040906/uk-social-media-statistics-2014> accessed 12 March 2014.

${ }^{75}<\mathrm{http}: / /$ press.linkedin.com/about $>$ accessed 14 March 2014.

${ }^{76}$ In 2011/2012 Pinterest had approximately 200,000 users in the UK. In the summer of 2013 this had grown to over 2 million: <http://socialmediatoday.com/kate-rose-mcgrory/2040906/uk-social-mediastatistics-2014> accessed 12 March 2014.

${ }^{77}$ Ibid.

${ }^{78}$ McGoldrick (n 41), 130; see also Twitter's fightback against depression, GQ Magazine, May 2014, 226. This article considers how the former professional footballer, Stan Collymore, used Twitter to document his depression to raise awareness of mental illness to help other sufferers; P. Bernal, $A$ defence of responsible tweeting, Comms. L. (2014), 19(1), 12-19, 14-15.

${ }^{79}$ A. Yen, Western Frontier or Feudal Society? Metaphors and Perceptions of Cyberspace, (2002) 17 Berkeley Technology Law Journal 1207; see also G. Benaim, A future with social media: Wild West or Utopia? You have a stake in the outcome $<\mathrm{http}$ ://inforrm.wordpress.com/2014/05/14/a-future-with-social-mediawild-west-or-utopia-you-have-a-stake-in-the-outcome-gideon-benaim/> accessed 16 May 2014.

${ }^{80}$ McGoldrick (n 41), 130-31.

${ }^{81}$ For example, see $R$ v Blackshaw [2011] EWCA Crim 2312.

${ }^{82}$ A 14-year-old Dutch girl was arrested by police in Rotterdam following a tweet made on 13 April 2014 to American Airlines, stating: ‘ AmericanAir hello my name's Ibrahim and I'm from Afghanistan. I'm part of Al Qaida and on June 1st I'm gonna do something really big bye'. Following her arrest American Airlines confirmed that it would pass on the girl's IP address to the FBI for investigation: See, A. Withnall, Twitter's American Airlines 'terror threat' 14-year-old girl arrested by police in Rotterdam, The Independent, 14 April $2014<\mathrm{http} / /$ www.independent.co.uk/life-style/ gadgets-and-tech/twitters-american-airlines-terror-threat-14yearold-girl-arrested-by-police-in-rotterd am-9259485.html>; J. McCully, Terror on Twitter $<$ http://inforrm.wordpress.com/2014/04/29/terroron-twitter-jonathan-mccully/\#more-26428> both accessed 30 April 2014.
} 
defamation, ${ }^{83}$ and have been subject to disciplinary proceedings, and in some cases, dismissal by their employer. ${ }^{84}$ Thus, a consequence of the ubiquity and diversity of these platforms, and the way in which they have ingrained themselves within our social cultural fabric, is that habits, conventions and social norms, that were once informal and transitory manifestations of social life, are now infused within social media platforms. What were casual and ephemeral actions and/or acts of expression, such as conversing with friends or colleagues or swapping/displaying pictures, or exchanging thoughts that were once kept private or maybe shared with a select few, have now become formalised and permanent. ${ }^{85}$ Social media's embodiment of the extension of man theory, and its transcendence of a physical filtration system, has meant that these actions and expressions are, in the click of mouse, or the flick of a finger, publicised for the world to see. They enter the 'public domain, with the potential for long-lasting and far reaching-consequences' ${ }^{86}$

The remainder of this section will illustrate the social media 'paradox' by considering some of the current issues regarding the use of social media and how these conflict with the notion of a purer form of freedom of expression. These clearly give rise to concerns regarding, for example, individuals' rights to privacy and reputation and their protection from harassment, bullying and threatening or abusive behaviour. Consequently, they set the scene for the final section, which looks at how some of these issues, in the context of criminal prosecutions, have been translated into litigation, and how the law, which was not drafted and devised with social media in mind, is coping.

\subsection{Speaker control: Snapchat and Twitter}

A concern with social media that has gained significant traction during 2013 and 2014 is the notion of 'speaker control'.

\footnotetext{
${ }^{83}$ For example, see Applause Store Productions Ltd v Raphael [2008] EWHC 1781; [2008] Info TLR 318; Cairns v Modi [2012] EWHC 756 (QB); [2012] EWCA Civ 1382; Tilbrook v Parr [2012] EHHC 1946 (QB). See also the recent Australian case of Mickle v Farley [2013] NSWDC 295 (Farley, a student, was ordered to pay Mickle, his teacher, A $\$ 105,000$ in damages for tweets sent to his followers) judgment accessible via <http:/www.caselaw.nsw.gov.au/action/pjudg?jgmtid=169992>; In the USA, a Nevada court recently ordered the founder of a 'revenge porn' site to pay US $\$ 250,000$ in damages for defamatory tweets stating that plaintiff was a pedophile who possessed child pornography: D, Lee, 'Revenge porn'site owner Hunter Moore sued for defamation, 11 March $2013<\mathrm{http}: / /$ www.bbc.co.uk/news/technology-21740386> accessed 30 April 2014.

${ }^{84}$ See generally, P. Landau, The antisocial network: why Facebook abuse is a matter for employers, The Guardian, 1 May $2012<\mathrm{http}: / /$ www.theguardian.com/money/work-blog/2012/may/01/antisocialnetwork-facebook-abuse-employers> accessed 30 April 2014; There have also been a number of instances involving, in particular, professional football players, who have been subject to disciplinary action by their club and the Football Association following the use of social media. For example, see generally: T. Lowles, Professional Footballers and Twitter: A match made in (tabloid) heaven <http:// inforrm.wordpress.com/2014/01/16/professional-footballers-and-twitter-a-match-made-in-tabloidheaven-tim-lowles/\#more-24668> accessed 30 April 2014; P. Coe, Social Media 'faux pas': there's only one 'tweeting' winner <http://inforrm.wordpress.com/2014/11/06/social-media-faux-pastheres-only-one-tweeting-winner-peter-coe/\#more-28332> accessed 1 December 2014.

${ }^{85}$ Van Dijck (n 5), 6-7.

${ }^{86} \mathrm{Ibid}$. See also Rowbottom (n 25), 366-77; The case of the then 17-year-old Paris Brown who stood down as Youth Police and Crime Commissioner over tweets she made when she was 14-16 years-old V. Dodd, Youth crime commissioner Paris Brown stands down over Twitter row, The Guardian, 9 April $2013<\mathrm{http} / / / \mathrm{www}$.theguardian.com/uk/2013/apr/09/paris-brown-stands-down-twitter> accessed 1 May 2014.
} 
For instance, in May 2014 it was announced that Snapchat had settled with the US Federal Trade Commission for misleading its users over data collection, and failing to inform them that their photos could be saved, thus raising concerns over the permanency of pictures taken using its mobile phone application. Snapchat markets its platform on the basis that the pictures, and any associated line of text applied to the picture, that are shared between users are transitory, as they 'self-destruct' after a predetermined (by the sender) number of seconds. ${ }^{87}$ However, by taking a screenshot of the picture, recipients are able to save the image and text permanently, with the potential to distribute it elsewhere via other social media platforms. There are also third-party applications available, such as Snapsaved, SnapHack and SnapBox, which enable the recipient to surreptitiously save photos they have received via Snapchat. ${ }^{88}$ These issues materialised in October 2014, when www.snapsaved.com, a third-party 'add-on' site used to 'store' Snapchat pictures, was hacked. Consequently, pictures stored by the application were made available online. As well as explicit pictures of celebrities, such as Matt Smith, Rihanna and Jennifer Lawrence, children were also affected, raising concerns over the use of the pictures within child pornography. This highlights the vulnerability of applications such as Snapchat that can be infiltrated by other, prohibited, add-on applications, despite the company's best efforts to remove them from the internet. Thus, in this instance, although Snapchat's servers were not breached, snapsaved's were. ${ }^{89}$ This follows 4.6 million Snapchat accounts being hacked in January 2014. Usernames and phone numbers were downloaded and made available online via a website called SnapchatDB. ${ }^{90}$

A key feature of Twitter is that user A can 're-tweet' user B's 'tweet' to user A's 'followers'. By virtue of user A's re-tweet, user B's post will be seen by a far wider audience than their group of followers. This process can continue to be extrapolated out. Consequently, a tweet to a relatively small group of individuals could end up being seen by a very large number of people. Incidentally, popular tweets and re-tweets can be categorised by Twitter as 'trending', meaning that popular 'discussions' appear on a trending list for all Twitter users to access.

Speaker control, in the context of Twitter and re-tweeting, or Snapchat and taking a screenshot of pictures, illustrates the paradoxical nature of social media. The instantaneous process of tweeting, or taking a picture and possibly adding a line of text, facilitates freedom of expression in its purest form. It is often unfiltered and, in the case of Twitter, by virtue of re-tweeting and trending, enables individuals to express themselves to a very wide audience. To the contrary, the re-tweeted audience or the recipients, via another social media

\footnotetext{
$\overline{{ }^{87} \text { At the time of writing Yahoo purchased a rival 'self-destructing' mobile messaging application }}$ called Blink, in order to acquire the application's developers to compete with platforms such as Snapchat: Yahoo buys self-destructing mobile messaging app Blink $<\mathrm{http}: / / \mathrm{www} . b b c . c o . u k / n e w s / b u s i n e s s-$ 27403813> accessed 16 May 2014.

${ }^{88}$ See generally: Snapchat settles with US regulators for deceiving users $<\mathrm{http}: / / \mathrm{www} . b b c . c o . u k /$ news/technology-27335255>; M. Himsworth, Snapchat Secrets: overshare and risks moving to new levels $<$ http://inforrm.wordpress.com/2014/05/13/snapchat-secrets-overshare-and-risks-movingto-new-levels-matt-himsworth/> both accessed 13 May 2014.

${ }^{89}$ Snapchat Hackers Post Explicit Images Online, 11 October $2014<\mathrm{http}: / /$ news.sky.com/story/ 1351147/snapchat-hackers-post-explicit-images-online>; C. Arthur, Third-party Snapchat Site claims photos were hacked from server, The Guardian, 13 October $2014<\mathrm{http}: / /$ www.theguardian. com/technology/2014/oct/13/third-party-snapchat-site-claims-says-pics-were-hacked-from-server $>$ both accessed 28 October 2014.

${ }^{90}$ Snapchat hack affects 4.6 million users, 2 January $2014<\mathrm{http}: / /$ www.bbc.co.uk/news/technology25572661> accessed 28 October 2014.
} 
platform of a surreptitiously saved Snapchat, may not be selected by them. They have no control over who sees their post or picture. Therefore, their freedom to express themselves is compromised by a lack of choice over their audience.

\subsection{Cyber-bullying (trolling) and 'revenge porn'}

In 2014, the National Society for the Protection of Cruelty to Children (NSPCC) published a report on 'The experiences of 11-16 year olds on social networking sites'. ${ }^{91}$ The research found that $28 \%$ of children with a social media profile experienced something that has upset them in the last year. ${ }^{92}$ These experiences included, inter alia: cyber-stalking (12\%); being subjected to aggressive or offensive language (18\%); receiving sexually explicit pictures $(12 \%)$; and being asked to provide personal or private information $(8 \%) .^{93}$ The greatest proportion of the group (37\%) had experienced 'trolling', ${ }^{94}$ defined by the report's authors as, 'any unkind, sarcastic or negative comments or rumours circulated online' ${ }^{95}$ These statistics mirror Childline's review of $2012 / 2013,{ }^{96}$ which found that there had been an $87 \%$ increase in young people contacting the charity for counselling about online bullying. This equates to 4500 young people accessing advice and support about being bullied via social media platforms, chat rooms, online gaming sites or via their mobile phones. ${ }^{97} \mathrm{~A}$ further report by Sky News makes it clear that online abuse is increasing and that it is not only suffered, but also perpetrated, by children. Over the last three years 1932 children have been subject to investigation regarding allegations of online abuse, offensive messages and online bullying. Of that number 1203 were, either, charged with a criminal offence, fined, cautioned or warned verbally. ${ }^{98}$

In March 2014, the House of Commons Culture Media and Sport Committee published its report on online safety, ${ }^{99}$ drawing on evidence, based on the statistics above, from the NSPCC, Childline and BeatBullying.org. ${ }^{100}$ The report makes reference to the range of

\footnotetext{
${ }^{91}$ C. Lilley, R. Ball, H. Vernon, The experiences of 11-16 year olds on social networking sites, NSPCC, 2014 available via <http://www.nspcc.org.uk/Inform/resourcesforprofessionals/onlinesafety/11-16-social-networking-report_wdf101574.pdf $>$. This follows previous research by the Society on younger children's use of social media: C. Lilley and R. Ball, Younger children and social networking sites: a blind spot, NSPCC, 2013 available via <http://www.nspcc.org.uk/ Inform/resourcesforprofessionals/onlinesafety/younger-children-report wdf99929.pdfs.

${ }^{92}$ Ibid. 12.

${ }^{93}$ Lilley et al (n 91), 13.

${ }^{94}$ Ibid.

${ }^{95}$ Lilley et al (n 91).

${ }^{96}$ Childline, What's Affecting Children in 2013: Can I tell you something? NSPCC, 2013 available via $<$ http://www.nspcc.org.uk/news-and-views/media-centre/press-releases/2014/childline-report/childline-report_can-i-tell-you-something_wdf100354.pdf $>$.

${ }^{97}$ Ibid. 40 .

${ }^{98}$ Of the 19,279 adults investigated over that period, 11,292 were subject to some of form of criminal action. According to responses from thirty-four of the UK's fifty-one police forces, 6,919 people were investigated in 2011/12 under section 127(1)(a) of the Communications Act 2003, including 744 children. In 2012/13, 6,974 cases were investigated, including 578 under-18s. After the first nine months of 2013/14, those figures were already at 7,318 and 610 respectively. See T. Cheshire, Online Abuse: Police Deal With Thousands of Kids, Sky News, 29 May $2014<$ http://news.sky.com/story/1271004/ online-abuse-police-deal-with-thousands-of-kids> accessed 29 May 2014.

${ }^{99}$ Culture, Media and Sport Committee - Sixth Report Online Safety, 13 March $2014<\mathrm{http}: / / \mathrm{www}$. publications.parliament.uk/pa/cm201314/cmselect/cmcumeds/729/72902.htm $>$ accessed 20 May 2014.

${ }^{100}$ Ibid. [88]-[92].
} 
legislation that currently applies to communications sent via social media, pursuant to which criminal offences can exist. These include: Protection from Harassment Act 1997; Malicious Communications Act 1988; Communications Act 2003; Offences Against the Person Act 1861; Computer Misuse Act 1990; Criminal Justice and Public Order Act 1994 and Sexual Offences Act 2003. ${ }^{101}$ In addition, the Director of Public Prosecutions (DPP) has published Interim Guidelines for prosecutors when considering cases involving communications via social media. ${ }^{102}$ The most commonly engaged provision has been section 127(1)(a) of the Communications Act 2003, which is dealt with in more detail in Section 5 below.

Although the report makes a number of recommendations, perhaps the most pertinent is the recognition that the raft of legislation that is currently being applied to deal with issues such as trolling is simply not fit for purpose, as they were not drafted for the social media era. This is illustrated by there being no specific criminal offence in the UK for cyber-bullying, despite the statistics cited above. ${ }^{103}$ In addition to the Committee's recommendation for new, consolidating legislation, it also asks for the status of both offline and online bullying to be clarified, along with guidance as to the interpretation of existing laws. ${ }^{104}$ This seems to have been, at least partly, heard by the Government as, in October 2014, Chris Grayling, the Justice Minister, announced that the Criminal Justice and Courts Bill ${ }^{105}$ would amend the offence of 'sending a letter, electronic communication or article of any description' which conveys a threat or abuse, pursuant to section 1 of the Malicious Communications Act, ${ }^{106}$ to a triable either way offence, with a maximum sentence of two years imprisonment. $^{107}$

'Revenge porn' has given rise to concerns, both in the $\mathrm{UK}^{108}$ and in the USA, ${ }^{109}$ over social media's impact on user's rights to privacy and reputation, and their protection from harassment and offences against the person. Essentially, it involves individuals uploading sexually explicit content of their ex-partners without permission. This content is made available via specific websites that link to the respective subjects' social media networks, enabling subjects' 'friends' or 'followers' to view the pictures.

At the time of writing, proposed amendments to the Criminal Justice and Courts Bill will make revenge porn a specific offence, carrying a maximum sentence of two years imprisonment. The offence will cover the sharing of images, both online and offline. This means that images posted to social networking sites, as well as those distributed by

\footnotetext{
${ }^{101}$ Culture, Media and Sport Committee - Sixth Report Online Safety (n 99), [93]-[94].

${ }^{102} \mathrm{CPS}$, Guidelines on prosecuting cases involving communications sent via social media, 19 December 2012 available via $<<\mathrm{http}: / /$ www.cps.gov.uk/legal/a_to_c/communications_sent_via_social_ media/s.

${ }^{103}$ Lilley et al (n 91), [96]-[97].

${ }^{104}$ Ibid. [97]; Conclusions and Recommendations [24].

${ }^{105}$ At the time of writing the Bill is at the Report stage. It enters the third Reading on the 10th of November 2014.

${ }^{106}$ Internet trolls to face 2 years in prison, 20 October $2014<$ https:/www.gov.uk/government/news/ internet-trolls-to-face-2-years-in-prison>; Internet trolls face up to two years in jail under new laws, 19 October $2014<$ http://www.bbc.co.uk/news/uk-29678989> both accessed 28 October 2014.

${ }^{107}$ Pursuant to $\mathrm{s} 1(4)$ the current maximum custodial sentence is six months imprisonment.

${ }^{108}$ At the time of writing, 149 allegations of revenge porn have been made in the past two and a half years: House of Lords agree to make revenge porn a criminal offence, 20 October $2014<\mathrm{http}$ ://www. bbc.co.uk/news/uk-politics-29697600> accessed 28 October 2014.

${ }^{109} \mathrm{G}$. Dawson, Revenge Porn is increasing in the UK, say charities $<\mathrm{http}: / / \mathrm{www} . b b c . c o . u k /$ newsbeat/ 26851276> accessed 13 May 2014; D. Lee, 'Revenge porn'site owner Hunter Moore sued for defamation, 11 March $2013<$ http://www.bbc.co.uk/news/technology-21740386> accessed 30 April 2014.
} 
text message, email or in hard copy will be captured. Photographs or films showing people engaged in sexual activity, or depicted in a sexual way, or with their genitals exposed, where what is shown would not usually be seen in public, will fall within its ambit. ${ }^{110}$ The change in the law follows campaigning by UK charities for legislation to be introduced that mirrors the USA ${ }^{111}$ where, according to the National Conference of State Legislatures, Bills criminalising revenge porn have been introduced, or are pending, in 27 states, with legislation already enacted in Arizona, Georgia, Idaho, Maryland, Utah, Virginia and Wisconsin. ${ }^{112}$

However, as the law currently stands revenge porn could, depending on the circumstances, potentially give rise to offences pursuant to, inter alia, the Protection from Harassment Act 1997, the Offences Against the Person Act 1861, Malicious Communications Act 1988 and the Communications Act 2003. Civil litigation could also ensue for defamation, ${ }^{113}$ breach of copyright ${ }^{114}$ or misuse of private information claims.

\subsection{The right to be forgotten}

In Google Spain SL, Google Inc. v Agencia Española de Protección de Datos, Mario Costeja González ${ }^{115}$ the Court of Justice of the European Union held that search engine operators are responsible for the processing of personal data appearing on web pages published by third parties. Consequently, individuals whose personal information appears pursuant to a search may request that search engines, such as Google or Yahoo, remove the links to the information, even though the initial publication of the information may have been lawful. ${ }^{116}$ If the information is 'inadequate, irrelevant or no longer relevant', it must be erased. ${ }^{117}$ The individual, subject to the data, is not required to demonstrate any prejudice emanating from the available information. ${ }^{118}$ This newly recognised right to be forgotten overrides the economic interests of search engines, and the general interest in freedom of information ${ }^{119}$ unless it appears that, for particular reasons, such as the role played by the individual subject to the data, in public life, that the interference with their right to be forgotten is justified by the preponderant interest of the general public in having, on account of its inclusion in the list of results, access to the information in question. $^{120}$

\footnotetext{
${ }^{110}$ New law to tackle revenge porn, 12 October $2014<\mathrm{https} / /$ www.gov.uk/government/news/newlaw-to-tackle-revenge-porn> accessed 28 October 2014.

${ }^{111}$ For an example from the USA see G. Dawson, Revenge Porn is increasing in the UK, say charities $<\mathrm{http} / / / \mathrm{www}$. bbc.co.uk/newsbeat/26851276> accessed 13 May 2014; D. Lee, 'Revenge porn' site owner Hunter Moore sued for defamation, 11 March $2013<\mathrm{http} / /$ www.bbc.co.uk/news/ technology-21740386> accessed 30 April 2014.

${ }^{112}<\mathrm{http}: / /$ www.ncsl.org/research/telecommunications-and-information-technology/state-revengeporn-legislation.aspx> accessed 21 May 2014.

${ }^{113}$ For an example from the USA see G. Dawson, Revenge Porn is increasing in the UK, say charities $<\mathrm{http}: / /$ www.bbc.co.uk/newsbeat/26851276> accessed 13 May 2014; D. Lee, 'Revenge porn' site owner Hunter Moore sued for defamation, 11 March $2013<\mathrm{http} / /$ www.bbc.co.uk/news/ technology-21740386> accessed 30 April 2014.

${ }^{114}$ If an intimate image has been taken as a 'selfie', the picture's copyright belongs to the 'taker'

${ }^{115}$ [2014] EUECJ C-131/12.

${ }^{116}$ Ibid. [89].

${ }^{117}$ Google Spain SL (n 115), [94].

${ }^{118}$ Ibid. [96].

${ }^{119}$ Google Spain SL (n 115), [91], [99].

${ }^{120}$ Ibid. [99].
} 
The potential impact of this judgment, and the right to be forgotten, once again demonstrates social media's paradoxical nature vis-à-vis the 'dangers' of the permanency of what is often instantaneous and unfiltered expression made via social media. For example, recent research carried out by the Chartered Institute of Personnel and Development found that two out of five employers look at candidates' online activity or social media profiles to inform their recruitment decisions. ${ }^{121}$ Thus, it seems that employers frequently base their decision on whether to interview or employ candidates on comments or pictures that were potentially posted or uploaded within a different context or at a different point in the candidate's life. The case of Paris Brown is a particularly good illustration. Brown was, for six days, the UK's first Youth Police and Crime Commissioner. However, the then 17-year-old stood down over comments she had posted on Twitter when she was aged 14-16, that could have been interpreted as being homophobic and racist. Brown gave a statement at the time of her resignation, stating that she had 'fallen into a trap of behaving with bravado on social networking sites', but she denied she held homophobic and racist views. Despite Ann Barnes, Kent's adult Police and Youth Crime Commissioner, opining that ' ... many people today would not have the jobs they are in if their thoughts in their teenage years were scrutinised ${ }^{122}$ a Google search for 'Paris Brown' still lists, within the top five results, a Daily Mail article from April 2013 calling her 'foul-mouthed' and 'offensive'. 123

\subsection{Public disorder}

On a State level, commentators have suggested that social media can manifest itself as an uncontrollable danger to society. ${ }^{124}$ This assertion, and the social media paradox, can be illustrated by the 2011 riots that began in London as a result of the shooting, by police, of Mark Duggan. In $R v$ Blackshaw ${ }^{125}$ evidence suggested that social media was used to coordinate riots and public disorder across the UK. According to Lord Judge CJ:

But modern technology has done away with the need for such direct personal communication. It can all be done through Facebook or other social media. In other words, the abuse of modern technology for criminal purposes extends to and includes incitement of very many people by a

\footnotetext{
${ }^{121}$ CIPD, Recruiting and pre-employment vetting in the social media era - CIPD publishes new guidance for employers, 9 December 2013 available via <http://www.cipd.co.uk/pressoffice/pressreleases/recruiting-pre-employment-vetting-social-media-era-cipd-publishes-new-guidance-employers91213.aspx>.

${ }^{122}$ Google: Who would want the right to be forgotten? 14 May $2014<\mathrm{http} / /$ www.bbc.co.uk/news/ magazine-27396981> accessed 21 May 2014. See also V. Dodd, Youth crime commissioner Paris

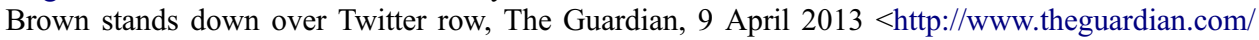
uk/2013/apr/09/paris-brown-stands-down-twitter> accessed 1 May 2014.

${ }^{123} \mathrm{~A}$. Edwards, Teenage youth crime commissioner who quit over offensive tweets is questioned by Special Branch, Mail Online, 20 April 2013 <http://www.dailymail.co.uk/news/article-2312044/ Paris-Brown-Foul-mouthed-youth-commissioner-quit-offensive-tweets-questioned-police-caution. html > accessed 21 May 2014.

${ }^{124}$ See generally: M. Mueller, Networks and States: The Global Politics of Internet Governance (MIT Press, 2010); McGoldrick (n 41), 130.

${ }^{125}$ [2011] EWCA Crim 2312; McGoldrick (n 41), 130. As McGoldrick notes, there is also evidence that social media was used in the Arab Spring to help facilitate democratic revolutions in the Arab World; At the time of writing social media had been used to organise an illegal rave on National Trust property in Surrey: See J. Loeb, Rave on: party at a beauty spot is too big for police to stop, The Times (26 May 2014), 15.
} 
single step. Indeed it is a sinister feature of these cases that modern technology almost certainly assisted rioters in other places to organise the rapid movement and congregation of disorderly groups in new and unpoliced areas. ${ }^{126}$

To the contrary, in the aftermath of the riots, representations were made by Blackberry, Facebook and Twitter to the UK Home Affairs Select Committee that, during the disturbances, social media was also used for good purposes, for example, by innocent people to ensure that their friends were safe, and by the police to organise their response. In the Select Committee's opinion it would be 'actively unhelpful to switch off social media during times of widespread and serious disorder'. ${ }^{127}$

\section{Domestic regulation of social expression: criminal law}

Clearly, the paradoxical nature of social media has an ability to enable the best and worst expression. As a consequence, it has become a new breeding ground for legal action. ${ }^{128}$ However, as discussed above, unlike the transitory nature of things said in passing, or in elation, anger or frustration, a 140-character Tweet, or a Facebook post, or a picture on Snapchat or Instagram are, predominantly, permanent. In a legal terrain, which remains largely uncharted, and is constantly shifting, the exponential growth of social media platforms demonstrates our obsession with them, and the increasing power they wield. Consequently, the permanency of this intersection between communication and technology creates complex challenges for the law, and the multitude of stakeholders engaged with social media. The HRC Rapporteur recognised the unique nature of the internet, and that regulations or restrictions which may be legitimate and proportionate for traditional media are not when it comes to new forms of media. ${ }^{129}$ Thus, applying laws designed for an era that did not have access to social media, let alone envisage it, have been inappropriate $^{130}$ and potentially incompatible with the right to freedom of expression. However, the exponential growth of social media, and the pace of change it has brought, has made it difficult, if not impossible for the law to adjust adequately, as illustrated by the criminal law.

\subsection{Communications Act 2003}

The provision most commonly engaged in relation to social media is section 127(1)(a) of the Communications Act $2003,{ }^{131}$ which makes it an offence to send:

... by means of a public electronic communications network a message or other matter that is grossly offensive or of an indecent, obscene or menacing character.

\footnotetext{
${ }^{126}$ Ibid. at [73].

${ }^{127}$ Policing Large Scale Disorder: Lessons from the Disturbances of August 2011, Sixteenth Report of Session 2010-2012, HC 1456-I, 27-30, 30.

${ }^{128} \mathrm{JJ}$. Henderson, The Boundaries of Free Speech in Social Media, in DR. Stewart (ed), Social Media and the Law, (Routledge, 2013), 1.

${ }^{129} \mathrm{La}$ Rue (n 10), [27].

${ }^{130}$ McGoldrick (n 41), 129; L. Scaife, The Regulation of Social Media, (2012) 14 E-Commerce Law \& Policy, 6.

${ }^{131}$ Cheshire (n 81); see also McGoldrick (n 41), 132 citing D. Ormerod, Telecommunications: Sending Grossly Offensive Message By Means of a Public Electronic Communications Network (2007) Criminal Law Review, Jan, 98-100.
} 
The offence is committed as soon as the message is sent. It does not matter whether it is received by the intended recipient or anybody else. ${ }^{132}$ According to the Crown Prosecution Service (CPS) the provision can be used as an alternative offence to such crimes as hate crime (including race, religion, disability, homophobic, sexual orientation and transphobic crime), hacking offences, cyber-bullying and cyber-stalking. ${ }^{133}$

\subsubsection{The meaning of 'grossly offensive'}

5.1.1.1. DPP $v$ Collins The leading judgment on what is meant by 'grossly offensive' was handed down by the House of Lords in DPP $v$ Collins, ${ }^{134}$ in which the respondent had made a series of racist telephone calls, and left similar answerphone messages, to the office of his MP. In considering whether an offence had been committed pursuant to section 127(1)(a), Lord Bingham stated that the standards of an open and just multi-racial society had to be taken into account, as well as the context within which the words were said, along with all the relevant circumstances. Thus, according to his Lordship:

There can be no yardstick of gross offensiveness otherwise than by the application of reasonably enlightened, but not perfectionist, contemporary standards to the particular message sent in its particular context. The test is whether a message is couched in terms liable to cause gross offence to those to whom it relates. ${ }^{135}$

Lord Bingham stressed that individuals are entitled to make their views known and to express them strongly. Thus, the appropriate question to be considered by judges in determining whether expression is grossly offensive is whether the language used is beyond the pale of what is tolerable in our society. ${ }^{136}$ His Lordship recognised that, prima facie, section 127(1)(a) does interfere with the right to freedom of expression, pursuant to Article 10(1) ECHR. However, its restriction is prescribed by Article 10(2) which is directed to a legitimate objective: preventing the use of a public electronic communications network for attacking the reputations and rights of others and, therefore, goes no further than is necessary in a democratic society to achieve that end. ${ }^{137}$

At this point it is worth revisiting the jurisprudence of the ECtHR (and the HRC). Article 10(1) has been interpreted to recognise a right for individuals to express themselves in way that is offensive, shocking or disturbing. No mention of this was made in Collins. There is a clear disconnect between the Collins' test of whether the message will cause gross offence to whom it relates/whether the language used is beyond the pale of what is tolerable in our society and the right to offend, shock or disturb. It is submitted that in exercising this right it is likely that the individual may 'go beyond the pale' of what is tolerable within society at that given time.

Social media exacerbates the apparent tension between freedom of expression and this test. As discussed above, individuals express themselves instantaneously, often without

\footnotetext{
132 DPP v Collins [2006] UKHL 40 per Lord Bingham, [8].

${ }^{133}$ Crown Prosecution Service, Improper use of public electronic communications network - Communications Act 2003, section 127, available via <http://www.cps.gov.uk/legal/a_to_c/ communications_offences/> accessed 21 May 2014.

${ }^{134}[2006]$ UKHL 40.

${ }^{135}$ Ibid. [9].

${ }^{136}$ Crown Prosecution Service (n 133), [12].

${ }^{137}$ Ibid. [14].
} 
filter. Very often this may be communicated to their 'society' or 'community', who they know will not take offence. However, as an 'extension of man', little thought is given to the fact that a 'wider society' may see it, or to its potential permanency. The following cases illustrate this point, and the difficulty in applying the test consistently in these circumstances.

\subsubsection{Daniel Thomas, Tom Daley and Twitter}

In July 2012 Daniel Thomas, a Welsh Premier League footballer, posted the following homophobic tweet on Twitter relating to Olympic divers Tom Daley and Peter Waterfield: 'If there is any consolation for finishing fourth at least Daley and Waterfield can go and bum each other \#teamHIV.' Although, initially, this was only tweeted to Thomas' followers, it was re-tweeted more widely. Thomas was arrested and the matter referred to the CPS to consider whether he should be charged with a criminal offence. Due to the publicity the case courted, the then DPP, Kier Starmer QC, issued a statement on social media communications. ${ }^{138}$ The DPP did not doubt that Thomas' message was offensive, and would be regarded as such by reasonable members of society. However, the question was whether the message was so 'grossly offensive' as to be criminal and, if so, whether a prosecution was required in the public interest. ${ }^{139}$ The DPP recognised that the distinction between offensive and grossly offensive is critical, but is not easy to make. Accordingly, the context and circumstances of the communication are relevant as is ECtHR's statement in Handyside. ${ }^{140}$

In relation to Thomas' case, in the DPP's opinion, the context and circumstances were particularly pertinent, for the following reasons: (a) However misguided, the message was intended to be humorous; (b) Although naive, there was no intention for the message to go beyond Thomas' followers, who were mainly friends and family; (c) Thomas took reasonably swift action to remove the message; (d) Thomas expressed remorse and was, for a period, suspended by his football club; ${ }^{141}$ (e) Neither Daley or Waterfield was the intended recipient of the message and neither knew of its existence until it was brought to their attention following reports in the media; (f) In essence, this was a one-off offensive Twitter message, intended for family and friends, which made its way into the public domain. It was not intended to reach Daley and Waterfield, it was not part of a campaign, it was not intended to incite others and Thomas removed it reasonably swiftly and has expressed remorse. ${ }^{142}$ Consequently, the prosecutor decided that it was not so grossly offensive that criminal charges needed to be brought.

\footnotetext{
$\overline{{ }^{138} \text { DPP statement on Tom Daley case and social media prosecutions, } 20 \text { September 2012, available }}$ via <http://blog.cps.gov.uk/2012/09/dpp-statement-on-tom-daley-case-and-social-media-prosecutio ns.html> accessed 22 May 2014.

${ }^{139}$ Ibid.

${ }^{140}$ DPP statement (n 138).

${ }^{141}$ Thomas was suspended for one match and ordered to pay a $£ 500$ fine: Tom Daley tweet: Port Talbot footballer Daniel Thomas fined <http://www.bbc.co.uk/news/uk-wales-south-west-wales-20512439> accessed 22 May 2014. A number of footballers have been suspended or fined by their clubs and/or the Football Association in relation to their use of social media. See generally: T. Lowles, Professional Footballers and Twitter: A match made in (tabloid) heaven $<\mathrm{http}$ ://inforrm.wordpress.com/2014/01/ 16/professional-footballers-and-twitter-a-match-made-in-tabloid-heaven-tim-lowles/\#more-24668> accessed 30 April 2014.

${ }^{142}$ DPP statement (n 138).
} 


\subsubsection{DPP $v$ Woods ${ }^{143}$ and other cases}

Nineteen-year-old Matthew Woods was sentenced to 12 weeks imprisonment for Facebook ‘jokes', relating to April Jones and Madeleine McCann, he made while drinking alcohol with friends. Public reaction led to him being arrested for his own safety and he subsequently pleaded guilty to the section 127(1)(a) offence. According to the prosecutor: 'He started this idea when he was at a friend's house, saw a joke on Sickipedia and changed it slightly'. ${ }^{144}$ By virtue of being posted on his Facebook page, the joke became available to a large number of people.

Woods' case was heard in the context of a number of other incidents involving offensive posts made on social media. For instance, Liam Stacey was jailed for 56 days after he tweeted 'LOL' (laugh out loud) in response to the footballer Fabrice Muamba's on-pitch collapse, and subsequent racist and offensive comments he made after other people who criticised him. ${ }^{145}$ In September 2012, Neil Swinburne was arrested over an offensive Facebook tribute page set-up following the fatal shootings of two female police officers in Manchester. $^{146}$

The decision to prosecute Woods seems to conflict with the DPP's statement relating to the treatment of Thomas, in particular the necessity to take into account the context and circumstances within which the communication was made (he was 19 years old at the time, he was with friends, he had consumed alcohol, a variation of the joke was already in the public domain on a well-known website) and the ECtHR's statement in Handyside. It is submitted that there is a clear difference between, on the one hand, Thomas and Woods-'type' communications that are offensive, immature and thoughtless but were one off, unfiltered and instantaneous manifestations of a thought, compared with, on the other hand, the Stacey and Swinburne-'type' communications, that were either sustained or, in the case of setting up a Facebook page, pre-meditated and thought-out.

\subsubsection{Of an indecent, obscene or menacing character}

The section 127(1)(a) offence can also be committed when the communication is of an indecent, obscene or menacing character. Chambers $v D P P^{147}$ concerned a tweet alleged to be of 'menacing character'.

\subsubsection{The 'Twitter joke trial'}

Paul Chambers was prosecuted and convicted for sending the following tweet, which, at first instance, was held to be of a 'menacing character': 'Crap! Robin Hood airport is closed. You've got a week and a bit to get your $\mathrm{s}^{* *} \mathrm{t}$ together otherwise I'm blowing the airport sky high!!'

Chambers' appeal to the Crown Court was dismissed on the basis that the tweet's content was menacing per se, and that an ordinary person seeing the tweet would see it in that way and be alarmed. ${ }^{148}$ This is despite Robin Hood Airport classifying Chambers'

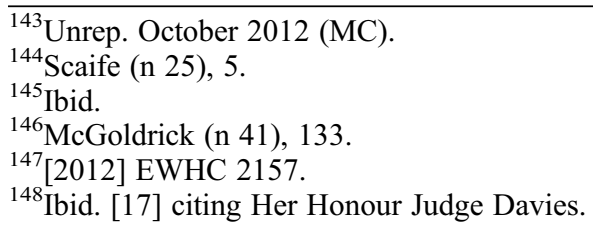


'threat' as 'non-credible', ${ }^{149}$ and that it was 'nothing other than a foolish comment posted as a joke for only his close friends to see'. ${ }^{150}$ Chambers subsequently appealed to the Divisional Court of the High Court, which took an entirely contrary view to the Crown Court, and allowed the appeal on the basis that the tweet did not constitute, or include, a message of a menacing character. ${ }^{151}$ According to Lord Judge CJ:

$\ldots$ if the person or persons who receive or read it, or may reasonably be expected to receive, or read it, would brush it aside as a silly joke, or a joke in bad taste, or empty bombastic or ridiculous banter, then it would be a contradiction in terms to describe it as a message of a menacing character. In short, a message which does not create fear or apprehension in those to whom it is communicated, or who may reasonably be expected to see it, falls outside this provision, for the very simple reason that the message lacks menace. ${ }^{152}$

Although his Lordship was clear that the 2003 Act was not drafted to interfere with freedom of expression, pursuant to Article $10(1)^{153}$ it is submitted that there is potential for prosecutions brought under section 127(1)(a) to face resistance from Article 10(1) ECHR, on the basis that the right to freedom of expression incorporates the right to offend, shock or disturb. Lord Judge CJ's judgment does not assimilate easily with the world of social media where, as can be seen above with regard to, for instance, 'speaker control' issues, there is no such thing as an audience who may be reasonably expected to receive or read a post, picture or tweet that is sent spontaneously, without filter. Thoughts, feelings and frustrated rants or inappropriate jokes can be sent, initially, to a very small group and then re-disseminated to a potentially unlimited audience. Although the initial 'group' may not see the message as being indecent, or obscene or menacing, members of a wider audience may do. In the context of 'grossly offensive' communications, the inability for his Lordship's test to work effectively in the context of social media communications is clearly apparent in the inconsistent decisions relating to Matthew Woods and Daniel Thomas.

\subsection{Other provisions applied to social media expression}

Other criminal law provisions that have been applied to social media expression include the Malicious Communications Act 1988, a piece of legislation drafted to deal with poison pen letters. ${ }^{154}$ Section 1 (1) provides that it is an offence to send to another person, inter alia, an electronic communication which conveys (a) (i) a message which is indecent or grossly offensive; (ii) a threat; (iii) information which is false and known or believed to be false by the sender; or (b) which is, in whole or part, of an indecent or grossly offensive nature, if one of the sender's purposes is to cause distress or anxiety to the recipient or any other person the sender intends the contents of the message to be communicated to. According to Haralambous and Johnson, the Act is unclear as to whether, for example, posts on Facebook constitute sending a message to another person. ${ }^{155}$ However, the Act has been applied to some digital communications, including social

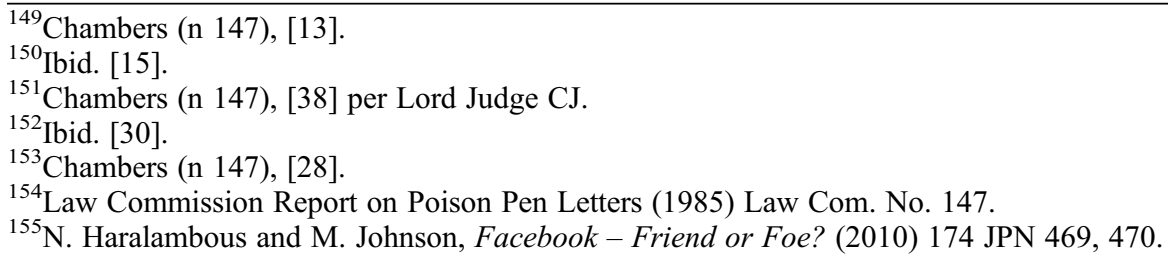


media expression. ${ }^{156}$ Provisions under the Protection from Harassment Act 1997 may also give rise to criminal liability for social media expression amounting to cyber-bullying (trolling) or online harassment. For instance, section 1 provides that a person must not pursue a course of conduct ${ }^{157}$ that amounts to harassment (alarming or causing the victim distress ${ }^{158}$ ) of another. Section 4 provides for the aggravated offence of putting the victim in fear of violence on at least two occasions. Section $2 \mathrm{~A}^{159}$ relates specifically to stalking ${ }^{160}$ and, by virtue of $\mathrm{s} 2 \mathrm{~A}(3)$, cyber-stalking. ${ }^{161}$

Section 4A of the Public Order Act 1986 provides that it is an offence for a person to use 'threatening, abusive or insulting words or behaviour, or disorderly behaviour' ${ }^{162}$ or display 'any writing, sign or other visible representation which is threatening, abusive or insulting' which causes 'that or another person harassment, alarm or distress'. ${ }^{163}$ Section 4 A(3) excludes from the ambit of the offence situations where the defendant and the recipient of the communication were inside a dwelling, thus offering some protection for private speech. ${ }^{164}$ However, according to the District Judge in $S v$ Director of Public Prosecutions $^{165}$ 'any person who posts material on the Internet puts that material within the public ambit'. ${ }^{166}$ As social media embodies the 'extension of man' theory, individuals can forget that what they are expressing is not communicated within a private arena, such as a dwelling. It is submitted that, to them, they are still 'in private', even though their thoughts and feelings can, potentially, be communicated to a very wide audience. Therefore, such communications, unless falling precisely within section $4 \mathrm{~A}(3)$, are within the 'public ambit', and are captured by the offence.

The mens rea of the offence provides some protection for social media expression, as it requires an intention to cause harassment, alarm or distress. However, the requirement that the speech is insulting, and causes distress, is a low threshold ${ }^{167}$ that clearly does not accord with the right to offend, shock or disturb. For instance, 'insulting banter' between individuals, that may have once remained within private arenas, such as a house or a pub, can now play out over social media, exposing individuals to potential prosecution. This concern is reflected by the judgment in Ajit Singh Dehal v Crown Prosecution Service ${ }^{168}$ where it was held that a prosecution under section 4A would not comply with Article 10 unless it was brought to maintain public order. ${ }^{169}$

\footnotetext{
$\overline{{ }^{156} \text { For example, in } 2012 \text { a man received a four month suspended sentence after an online discussion }}$ about football resulted in him posting a tweet referring to Newcastle United as 'Coon Army': The Northern Echo, 28 February 2012.

${ }^{157}$ Section 7(3) provides that, in relation to a single person, a course of conduct must involve conduct on at least 2 occasions.

${ }^{158}$ Section 7(2); DPP v Ramsdale [2001] EWHC Admin 106.

${ }^{159}$ Inserted by section 111 of the Protection of Freedoms Act 2012.

${ }^{160}$ Section $4 \mathrm{~A}$ provides for the aggravated offence of stalking involving fear of violence or serious alarm or distress.

${ }^{161}$ See generally: J. Agate and J. Ledward, Social media: how the net is closing in on cyber bullies, Ent. L.R. 2013, 24(8), 263-68; N. MacEwan, The new stalking offences in English law: will they provide effective protection from cyberstalking? Crim. L.R. 2012, 10, 767-81.

${ }^{162}$ Section 4A(1)(a).

${ }^{163}$ Section 4A(1)(b).

${ }^{164}$ Rowbottom (n 25), 360.

165 [2008] EWHC 438 (Admin).

${ }^{166}$ Ibid. [4] per Lord Justice Maurice Kay citing the District Judge.

${ }^{167}$ Rowbottom (n 25), 360.

${ }^{168}$ [2005] EWHC 2154 (Admin).

${ }^{169}$ Ibid. [12].
} 
Section 5 of the Act is broader in application as it does not require the communication to actually cause harassment, alarm or distress, ${ }^{170}$ or that the communicator intends this. However, section $5(1)(\mathrm{b})$ requires that the words or behaviour 'be within the hearing or sight of a person likely to be caused harassment, alarm or distress thereby'. It remains unclear whether social media communications are within the ambit of section 5(1)(b), or if it applies exclusively to physical proximity. For example, Maurice Kay LJ's judgment in $S v D P P$ implies that the provision does not apply to websites as, according to his Lordship, the omission in section $4 \mathrm{~A}$ of the 'within sight or hearing' requirement 'was conditioned by an appreciation of the problems created by the posting of offensive material on websites'. ${ }^{171}$ However, as Rowbottom suggests, this case does not provide a definitive statement of the law, as it relates to whether, for the purposes of section 4A, the victim must actually see the material on the internet, or if it is sufficient to be made aware of its existence or shown a copy by a third party at a later date. ${ }^{172}$ Other commentators are of the opinion that the section does apply to expression on the internet. ${ }^{173}$

If social media expression does come within the province of the provision, it creates clear tension with the right to freedom of expression. For example, a person may post an abusive or insulting message on Facebook or a tweet to their followers knowing that this 'community' would not be caused harassment, alarm or distress. However, as this is a 'conduct crime', meaning that there is no requirement that harm is actually caused to an individual for a successful prosecution to ensue, if that message or tweet is disseminated, beyond their control, to a wider audience, an offence could be committed so long as it is seen by somebody likely to be caused harassment, alarm or distress.

\subsubsection{Freedom of expression and the DPP's interim guidelines}

The apparent 'tension' between the array of criminal law provisions that could be engaged in relation to social media communications and freedom of expression, and the jurisprudence of the ECtHR and HRC, did not go unnoticed by the previous DPP, when he made his statement on social media prosecutions. The statement recognised that the context within which real-time social media expression and interaction occurs is different from that within which other communication and expression takes place. Consequently, in cases involving social media, the CPS has to balance 'the fundamental right of free speech and the need to prosecute serious wrongdoing on a case by case basis'. ${ }^{174}$ The DPP recognised that the CPS was making very difficult judgment calls on whether or not to prosecute, as social media expression was (and still is) largely uncharted terrain:

In some cases it is clear that a criminal prosecution is the appropriate response to conduct which is complained about, for example where there is a sustained campaign of harassment of an individual, where court orders are flouted or where grossly offensive or threatening remarks are made and maintained. But in many other cases a criminal prosecution will not be the appropriate response. If the fundamental right to free speech is to be respected, the threshold for criminal prosecution has to be a high one and a prosecution has to be required in the public interest. ${ }^{175}$

\footnotetext{
${ }^{170}$ Norwood v DPP [2003] EWHC 1564.

${ }^{171} S v D P P,[12]$ and [15] per Maurice Kay LJ.

${ }^{172}$ Rowbottom (n 25), 361 .

${ }^{173}$ N. Haralambous and N. Geach, Regulating Harassment: Is the Law Fit for the Social Networking Age? (2009) 73(3) Journal of Criminal Law 241, 256-56.

${ }^{174}$ DPP statement (n 138).

${ }^{175}$ Ibid.
} 
The DPP announced in the statement that he intended to issue Interim Guidelines for prosecutors dealing social media cases. He also stated that '[s]ocial media is a new and emerging phenomenon raising difficult issues of principle ... the time has come for an informed debate about the boundaries of free speech in an age of social media'. ${ }^{176}$

The Interim Guidelines ${ }^{177}$ distinguish between two categories of cases. Category one includes communications: which may constitute credible threats of violence to persons or damage to property; which specifically target one or more individuals; which may amount to a breach of a court order. ${ }^{178}$ This category of communications must be prosecuted robustly. ${ }^{179}$ Category two incorporates communications that may be considered grossly offensive, indecent, obscene or false. ${ }^{180}$ Such communications will be subject to a high threshold, and in many cases a prosecution is unlikely to be in the public interest, ${ }^{181}$ although they are not precluded from prosecution.

According to the Guidelines the rationale behind categorising communications in this way is due to the potential 'chilling effect' prosecutions relating to social media expression may have on freedom of expression. ${ }^{182}$ Thus, the Guidelines were drafted with the intention of ensuring compliance with Article $10 .{ }^{183}$ This is clearly evidenced with respect to the high threshold, as the Guidelines state that the common law and applicable legislation must be interpreted consistently with Article 10 as interpreted by ECtHR jurisprudence, ${ }^{184}$ including Handyside.

The Guidelines' common sense approach to social media expression is illustrated further in the context of sections 1 and 127(1)(a) of the Malicious Communications Act 1988 and Communications Act 2003 respectively, in that it reminds prosecutors that what is prohibited under these provisions is the sending of a communication that is grossly offensive. Accordingly, a communication has to be more than simply offensive to be contrary to the criminal law. Therefore, just because the content expressed in the communication is in bad taste, controversial or unpopular, and may cause offence to individuals or a specific community, does not, in itself, require the engagement of the criminal law. ${ }^{185}$ Furthermore, prosecutors are required to consider the context in which real-time social media communications operate and to have regard to the fact that '[a]ccess is ubiquitous and instantaneous. Banter, jokes and offensive comments are commonplace and often spontaneous. Communications intended for a few may reach millions'. ${ }^{186}$ Consequently, prosecutors should only proceed with prosecutions pursuant to these provisions where, on the facts and merits of the individual case a prosecution is both necessary and proportionate in accordance with Article 10, ${ }^{187}$ and they are satisfied that the communication in question

\footnotetext{
${ }^{176}$ DPP statement (n 138).

${ }^{177}$ CPS Guidelines (n 102).

${ }^{178}$ Ibid. [12].

${ }^{179}$ CPS Guidelines (n 102), [13].

${ }^{180}$ Ibid. [12].

${ }^{181}$ CPS Guidelines (n 102), [13].

${ }^{182}$ Ibid. [29].

${ }^{183}$ CPS Guidelines (n 102), [30]-[36]; see also McGoldrick (n 41), 136.

${ }^{184}$ Ibid. [30]-[33].

${ }^{185}$ CPS Guidelines (n 102), [34].

${ }^{186}$ Ibid. [35].

${ }^{187}$ CPS Guidelines (n 102), [38]-[39]; A prosecution is unlikely to be both necessary and proportionate where: (a) The suspect has swiftly taken action to remove the communication or expressed genuine remorse; (b) Swift and effective action has been taken by others for example, service providers, to remove the communication in question or otherwise block access to it; (c) The communication was
} 
is more than: offensive, shocking or disturbing; or satirical, iconoclastic or rude comment; or the expression of unpopular or unfashionable opinion about serious or trivial matters, or banter or humour, even if distasteful to some or painful to those subjected to it. If satisfied, prosecutors should go on to consider whether a prosecution is required in the public interest. ${ }^{188}$ Finally, the age and maturity of suspects should be given significant weight, as children may not appreciate the potential harm and seriousness of their communications. In these instances, a prosecution will rarely be in the public interest. ${ }^{189}$

\section{Conclusion}

The use of different criminal law legislation, designed and drafted for a time before the advent of social media, effectively re-contextualises the application of these provisions. Instead of applying to an environment where a parent, teacher or police officer could provide a warning to an individual using, for instance, threatening or abusive language, they now operate in a world where the individual who posts a tweet, or shares a Snapchat or Instagram image, will have a very different idea as to their responsibilities and, by virtue of the remoteness of the online world, the consequences that may ensue from their actions. As an extension of man, the use of social media erodes individuals' perceptions of private and public boundaries, meaning the public arena is effectively blurred with their 'private community'. Clearly, had the Guidelines been in place at the time the prosecutions dealt with above were initiated, a more contextualised and consistent approach, in line with Article 10 and its jurisprudence, may have been applied. It is submitted that the Guidelines can bring a semblance of order to the multitude of legislation and common law jurisprudence that can be applied to social media communications. They effectively mitigate, what was (and, to an extent, still is), a 'square peg round hole' regime. Thus, prima facie the Guidelines, and the common sense and contextualised approach they advocate, accord with ECHR, ECtHR, ICCPR and HRC principles of freedom of expression. Furthermore, it is submitted that these Guidelines, in theory, have the potential to provide the equilibrium that is needed to both protect individuals and facilitate the notion of a purer form of expression, exercised through the use of social media.

However, the overall impact of the criminalisation of expression remains to be seen. A recent Sky News investigation provides some insight into the Guidelines potential longterm effect. According to the report, almost 23,000 people have been investigated by police in the last three years relating to social media abuse, offensive Twitter messages and online bullying, equating to 20 cases per day; a 5\% increase on 2011. Despite the higher threshold set by the Guidelines, and the requirement for prosecutors to consider the context in which the communication was made, including giving weight to the age of the communicator, ${ }^{190}$ these figures look as though they will continue to rise. Prosecutions pursuant to section 127(1)(a) of the Communications Act 2003 continue to be the preferred

not intended for a wide audience, nor was that the obvious consequence of sending the communication; particularly where the intended audience did not include the victim or target of the communication in question; or (d) The content of the communication did not obviously go beyond what could conceivably be tolerable or acceptable in an open and diverse society which upholds and respects freedom of expression.

${ }^{188}$ Ibid. [36].

${ }^{189}$ CPS Guidelines (n 102), [41].

${ }^{190}$ Cheshire (n 81): It is clear from the report that children are increasingly been prosecuted for offences stemming from the use of social media. 
option for the CPS, as evidenced by the following statistics, provided by 34 of the UK's 51 police forces: In 2011/12, 919 people were investigated. This rose to 6974 in 2012/13 and, in the first nine months of 2013/14, 7318 people had already been subjected to investigation. $^{191}$

\section{Disclosure statement}

No potential conflict of interest was reported by the author. 